\title{
KLASIFIKASI HABITAT BENTIK PERAIRAN DANGKAL DARI CITRA WORLDVIEW-2 MENGGUNAKAN DATA IN-SITU DAN DRONE
}

\section{BENTHIC HABITAT CLASSIFICATION OF SHALLOW WATER USING WORLDVIEW-2 IMAGERY WITH IN-SITU AND DRONE DATA}

\author{
Ayub Sugara1, Vincentius P. Siregar2, \& Syamsul B. Agus ${ }^{2}$ \\ ${ }^{1}$ Program Studi Teknologi Kelautan, FPIK, Sekolah Pascasarjana IPB, \\ Bogor, 16680, Indonesia \\ ${ }^{2}$ Departemen Ilmu dan Teknologi Kelautan, FPIK-IPB, Bogor, 16680, Indonesia \\ *E-mail: ayubsugara7@gmail.com
}

\begin{abstract}
The Worldview-2 imagery application with groud truth habitat data still has shortcomings that require a long time, limited access, high costs and risk factors. Surveying techniques using drones can reduce these limitations. This study aims to classify and test the accuracy of shallow water habitat classification results in Lancang Island and Sebaru Besar Island from Worldview-2 imagery with ground truth habitat (GTH) and virtual ground truth (VGT) input data and explore the spatial resolution of drone images at altitude different. Overall accuracy results were obtained for 7 habitat classes on Lancang Island with GTH and VGT data of $65.5 \%$ and $60.6 \%$, respectively. Whereas in Sebaru Besar Island they were $67.5 \%$ and $64.6 \%$, respectively. Comparison of the accuracy of the classification results obtained $4.9 \%$ selisi on Lancang Island and $2.9 \%$ on Sebaru Besar Island. Significance test results of the GTH and VGT methods on Lancang Island were significantly different with a $Z$ value of 2.0851, while on Sebaru Besar Island it was not significantly different from the $Z$ value of 0.5255, so that benthic habitat mapping with the VGT method could be used as an alternative in-situ field observation, however this still requires further research.
\end{abstract}

Keywords: drones, GTH, high resolution satellites, photogrametry, VGT

\begin{abstract}
ABSTRAK
Aplikasi citra Worldview-2 dengan data groud truth habitat masih memiliki kekurangan yaitu membutuhkan waktu yang lama, akses yang terbatas, biaya yang tinggi serta faktor resiko. Teknik survei menggunakan drone dapat mengurangi keterbatasan tersebut. Penelitian ini bertujuan untuk melakukan klasifikasi dan uji akurasi hasil klasifikasi habitat perairan dangkal di Pulau Lancang dan Pulau Sebaru Besar dari citra Worldview-2 dengan inputan data ground truth habitat (GTH) dan virtual ground truth (VGT) serta mengeksplorasi resolusi spasial citra drone pada ketinggian yang berbeda. Hasil overall accuraccy diperoleh untuk 7 kelas habitat di Pulau Lancang dengan data GTH dan VGT masing-masing sebesar 65,5\% dan 60,6\%. Sedangkan di Pulau Sebaru Besar masing-masing sebesar $67,5 \%$ dan 64,6\%. Perbandingan akurasi hasil klasifikasi didapat selisih 4,9\% di Pulau Lancang dan 2,9\% di Pulau Sebaru Besar. Hasil uji signifikansi metode GTH dan VGT di Pulau Lancang berbeda nyata dengan nilai Z sebesar 2,0851, sedangkan di Pulau Sebaru Besar tidak berbeda nyata dengan nilai $Z$ sebesar 0,5255 , sehingga pemetaan habitat bentik dengan metode VGT dapat digunakan sebagai alternatif pengamatan di lapangan secara in-situ, namun ini masih memerlukan penelitian lanjutan.
\end{abstract}

Kata kunci: drone, fotogrametri, GTH, satelit resolusi tinggi, VGT

\section{PENDAHULUAN}

Penginderaan jauh adalah salah satu teknologi untuk mendukung penelitian mengenai pemetaan suatu area kawasan maupun pengamatan lingkungan. Penginderaan jauh pada umumnya hanya menggunakan dua sumber yaitu citra satelit 
dan citra dari pesawat berawak (Green et al., 2000). Citra satelit memiliki keunggulan dapat meliput area kajian yang luas dan beberapa citra satelit resolusi spasial rendah sudah tersedia secara gratis (Sulong et al., 2002). Penginderaan jauh dari satelit dapat menjadi metode pelengkap dari proses pemetaan (Hedley et al., 2016). Ruang lingkup dari aplikasi penginderaan jauh meliputi peta skala sangat besar hingga peta skala yang sangat kecil (Danoedoro, 2012). Penginderaan jauh di bidang kelautan antara lain digunakan untuk mengetahui sebaran habitat bentik dan monitoring ekosistem perairan dangkal (Richards, 2013)

Habitat bentik adalah zona atau lingkungan tempat hidup bagi bentos atau organisme perairan yang hidup pada substrat dasar suatu perairan (BIG, 2017). Habitat bentik perairan dangkal secara ekologis memiliki keanekaragaman karakteristik penyusun substrat dasar perairan seperti ekosistem terumbu karang dan lamun yang perlu dipetakan sebagai upaya untuk mengetahui keanekaragaman objek penyusun dasar perairan.

Teknologi penginderaan jauh dengan citra resolusi tinggi dapat meningkatkan akurasi deteksi terhadap habitat terumbu karang (Mellin et al., 2009). Kemajuan dalam teknologi penginderaan jauh memungkinkan peneliti menggunakan drone sensor tunggal cahaya tampak (single visible light camera sensor) sebagai pengganti data GTH. Penggunaan drone memungkinkan peneliti meminimalisir permasalahan pengambilan data lapangan, seperti lama waktu, akses yang sulit, high cost (Ratcliffe et al., 2015). Metode pengambilan data foto udara menggunakan drone dikenal dengan teknik fotogrametri. Waugh \& Mowlem (2010) menyebutkan bahwa salah satu jenis wahana foto udara dengan jenis Aerosonde telah dikembangkan secara komersial sejak tahun 1993 dan dipergunkan untuk misi ilmiah. Teknik survei dengan biaya yang murah dalam dekade terakhir, dikembangkan dengan menggunakan pesawat udara tanpa awak (drone) yang dioperasikan jarak jauh (Colefax et al., 2017; Kiszka et al., 2016). Munculnya drone dengan harga yang ekonomis menimbulkan potensi besar sebagai alat untuk dapat menganalisis lingkungan dan ekologi, seperti pemantauan persebaran lumut di kutub, lahan pertanian, kebakaran hutan, dan pemetaan hutan bakau (Crutsinger et al., 2016; Floreano \& Robert, 2015).

Citra foto udara resolusi tinggi yang dihasilkan dengan drone, dapat dilakukan pengulangan secara deret waktu (time series) pada lokasi yang sama sehingga dapat dilakukan kajian tentang dampak perubahan pada penutupan ekosistem terumbu karang yang dihubungkan dengan fenomena tertentu (Casella et al., 2017). Schaub et al. (2018) menyatakan aplikasi drone dengan survei insitu dapat memperoleh informasi tentang agregasi spesies ubur-ubur seperti jumlah, kepadatan, ukuran-frekuensi, dan biomassa di Danau Smiths, Australia. Penelitian ini menggunakan drone dengan sensor tunggal cahaya tampak (single visible light camera sensor), sehingga setiap data foto yang dihasilkan hanya menghasilkan band RGB yang di orthomosaic menjadi data citra drone. Selanjutnya citra drone dikoreksi geometrik serta melakukan visualisasi objek habitat bentik perairan dangkal pada citra drone yang dikenal dengan metode VGT.

Citra drone yang dihasilkan dapat digunakan sebagai pendukung titik pada lokasi survei yang sulit terjangkau serta memiliki tingkat resiko yang tinggi. Menurut Colomina \& Molina (2014) citra foto udara resolusi tinggi memberikan keuntungan karena dapat membantu kegiatan survei pada daerah-daerah yang sulit. Penelitian ini bertujuan untuk mengetahui tingkat akurasi klasifikasi dengan menggunakan data GTH dan VGT pada citra Worldview-2 di Pulau Lancang dan Pulau Sebaru Besar serta mengeksplorasi lebih jauh fungsi dari fotografi udara menggunakan drone. Pendekatan teknologi fotografi udara diharapkan dapat menjadi alternatif pe- 
ngambilan data lapangan, mengurangi waktu GTH yang terlalu lama.

\section{METODE PENELITIAN}

\subsection{Waktu dan Lokasi}

Penelitian ini dilaksanakan di dua tempat yaitu di Pulau Lancang dengan posisi $5^{\circ} 55^{\prime} 24.8^{\prime \prime} \mathrm{LS}-5^{\circ} 566^{\prime 28.4}$ "LS dan 106 $34^{\prime} 48$. 2"BT-106³5'52.1"BT serta Pulau Sebaru Besar dengan posisi $5^{\circ} 30^{\prime} 27.0^{\prime \prime} L S-5^{\circ} 29^{\prime} 44$. 2"LS dan $106^{\circ} 33^{\prime} 32.8^{\prime \prime B T}-106^{\circ} 32^{\prime} 20.3^{\prime \prime B T}$. Survei lapangan dalam penelitian ini dilakukan tanggal 03-12 Mei 2018 dan 04-10 Desember 2018.

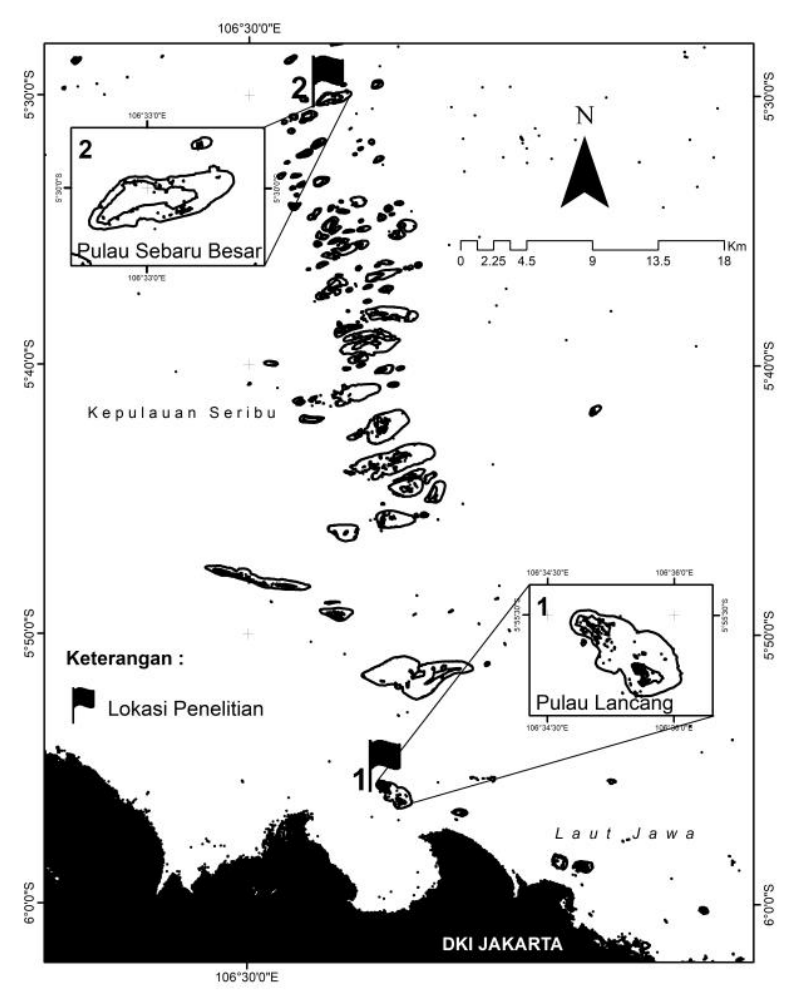

Figure 1. Map of research location.

\subsection{Bahan dan Data}

Bahan yang digunakan yaitu Citra Worldview-2 (standar level 1B 11 bit) hasil akuisisi 03 April 2018 dengan sistem koordinat UTM 48S-WGS84 dengan resolusi spasial $2 \mathrm{~m}$ sedangkan band pankromatiknya dengan resolusi spasial $0,5 \mathrm{~m}$. Peralatan yang digunakan terbagi dua yaitu peralatan lapangan dan laboratorium. Peralatan lapangan meliputi: GPS Handheld 78S dan 64S, SCUBA Set, underwater camera, alat tulis, kertas bawah air (newtop), transek kuadrat (Roelfsema \& Phinn, 2008; Siregar, 2010) berukuran $1 \mathrm{~m} \times 1 \mathrm{~m}$ yang telah dimodifikasi dengan pipa penyangga (tetrapod), dan drone (Table 1).

Peralatan laboratorium yang dibutuhkan meliputi: komputer, perangkat lunak MS Excel, XLSTAT, perangkat lunak pengolahan data citra satelit ENVI 5.2, perangkat lunak pengolahan data spasial ArcGIS 10.4, Agisoft PhotoScan untuk pengolahan data foto udara dan persentase tutupan setiap foto dianalisis dengan perangkat lunak Coral Point Count with Excel extensions (CPCe).

\subsection{Data Lapangan}

Jumlah titik GTH di Pulau Lancang sebanyak 128 titik dan Pulau Sebaru Besar sebanyak 159 titik (Figure 2). Setiap titik lokasi sampling dilakukan dua kali foto dengan menggunakan transek kuadrat $1 \mathrm{~m} x$ $1 \mathrm{~m}$ untuk mewakili komposisi habitat bentik pada satu piksel Citra Worldview-2 dengan resolusi spasial $2 \mathrm{~m}$. Pengambilan data habitat bentik dilakukan dengan metode systematic random sampling, dimana setiap titik pengamatan memiliki jarak $40 \mathrm{~m}$ antara titik pengambilan data lainnya. Titik pengamatan menyebar pada lokasi penelitian untuk keterwakilan dari setiap objek. Pengamatan dilakukan dengan 7 kali penerbangan dan menghasilkan 1.698 foto udara di Pulau Lancang dan 5 kali penerbangan menghasilkan 1.157 foto udara di Pulau Sebaru Besar dengan overlapping $70 \%$ dan $80 \%$ sedangkan tinggi dijelaskan pada Table 2. Jalur terbang diprogram menggunakan perangkat lunak Pix4D Capture pada mobile phone (Figure 2).

Tahapan berikutnya adalah VGT yang dilakukan untuk membantu survei pada area yang sulit dijangkau dan memiliki tingkat bahaya yang tinggi. VGT adalah interpretasi visual objek habitat bentik perairan dangkal dari citra 
drone yang telah dikoreksi secara geometrik. Data VGT di Pulau Lancang dan Pulau Sebaru Besar diperoleh dari 25 titik dari tiap kelas. Analisis persentase tutupan setiap foto dianalisis dengan perangkat lunak $\mathrm{CPCe}$ (Kohler \& Gill, 2006). Selanjutnya dianalisis cluster (AHC) dengan perangkat lunak
XLSTAT menggunakan algoritma braycurtis sehingga dihasilkan dendogram skema klasifikasi habitat bentik berdasarkan data survei lapangan dengan menghilangkan komposisi kelas yang memiliki frekuensi kehadiran kurang dari 40\% (Green et al., 2000).

Table 1. Specifications of DJI Phantom 3 Professional and DJI Mavic Pro.

\begin{tabular}{lll}
\hline \multirow{2}{*}{ Characteristic } & \multicolumn{2}{c}{ Drone type } \\
\cline { 2 - 3 } Sensor & \multicolumn{1}{c}{ DJI Phantom 3 Pro } & \multicolumn{1}{c}{ DJI Mavic Pro } \\
Lens & Sony EXMOR & CMOS $1 / 2.3^{\prime \prime}$ \\
Camera resolution & FOV $94^{\circ} 20 \mathrm{~mm} \mathrm{f} / 2.8$ & FOV $78.8^{\circ}, 28 \mathrm{~mm} \mathrm{f} / 2.2$ \\
ISO range & $12 \mathrm{MP}$ & $12 \mathrm{MP}$ \\
& $100-3200$ for video & $100-3200$ for video \\
Photo size & and $100-1600$ for photo & dan $100-1600$ for photo \\
Focal length & $4000 \times 3000$ & $4000 \times 3000$ \\
Remote control frequency & $3.61 \mathrm{~mm}$ & $4.73 \mathrm{~mm}$ \\
Battrery capacity & $2.400 \mathrm{GHz}-2.4835 \mathrm{GHz}$ & $2.400 \mathrm{GHz}-2.4835 \mathrm{GHz}$ \\
Satellite position system & $4480 \mathrm{mAh}$ & $3830 \mathrm{mAh}$ \\
\hline Source: & GPS/GLONASS & GPS/GLONASS \\
\hline
\end{tabular}

Source: www.dji.com

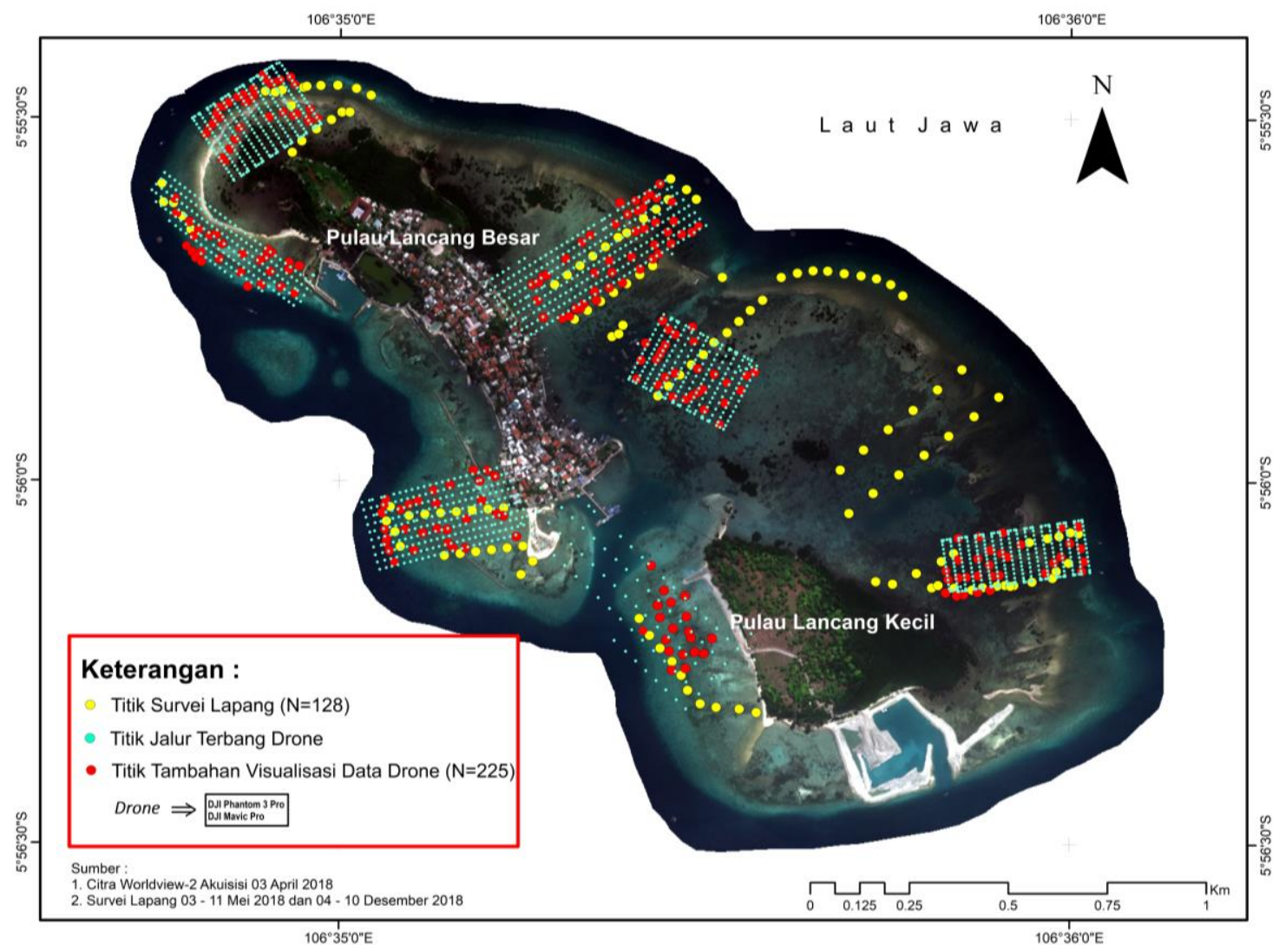

(a) 


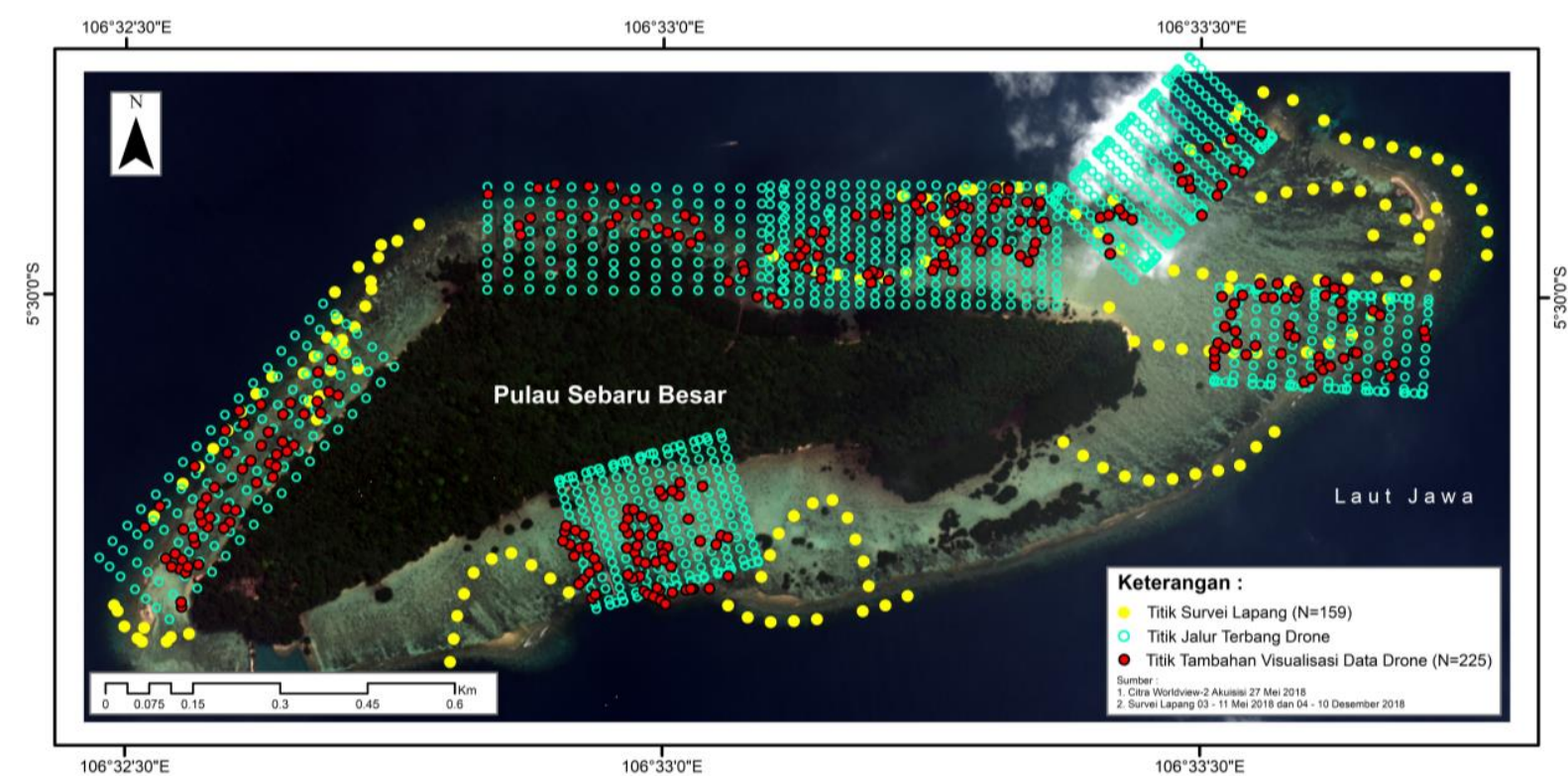

(b)

Figure 2. Map of field observation points and drone flyways in (a) Lancang Island (b) Sebaru Besar Island.

\subsection{Pengolahan Citra Satelit}

Koreksi atmosferik dilakukan dalam prapengolahan Citra Worldview-2 menggunakan perangkat lunak ENVI 5.2 dengan metode dark object subtraction (DOS). Objek yang memiliki piksel minimum dijadikan sebagai acuan dalam metode ini. Proses selanjutnya, citra terkoreksi atmosferik dan digunakan sebagai input pada pengolahan citra yaitu proses supervised classification menggunakan algoritma maximum likelihood classification dengan perangkat lunak ENVI 5.2. Klasifikasi ini dilakukan dengan memberikan input berupa titik sampel GTH dan VGT yang telah memiliki data atribut habitat bentik peda masing-masing kelas yang diperoleh saat survei lapangan.

\subsection{Teknik Fotogrametri}

Teknik fotogrametri terdiri atas koreksi data foto udara, melakukan identifikasi data foto udara, melakukan triangulasi dari data foto udara yang dihasilkan, tahapan pembangunan permukaan digital dan orthorektifikasi. Pada tahapan ini foto udara yang didapat dari hasil pemetaan pada lokasi penelitian diproses menggunakan perangkat lunak Agisoft PhotoScan. Dua belas jalur terbang drone di Pulau Lancang dan Pulau Sebaru Besar menghasilkan 12 citra foto udara. Proses pertama yaitu add photo berfungsi untuk memasukan seluruh data foto udatra yang akan diolah menggunakan perangkat lunak Agisoft PhotoScan. Selanjutnya dilakukan penyelarasan antara masing-masing foto (aligning photo) yang berfungsi untuk menggabungkan satu foto yang memiliki informasi spasial dengan foto lainnya dengan mencari titik ikat (tie point) atau kesamaan piksel yang terdapat pada setiap foto.

Setelah penyelarasan antara masingmasing foto, dibangun titik awan padat (build dense cloud) berdasarkan ketentuan titik awan jarang dengan memperkirakan posisi kamera dalam mencari kesamaan piksel berdasarkan titik awan sebelumnya. Kemudian membangun mesh yang merupakan tahapan proses membangun model permukaan dari titik awan padat yang telah dihasilkan. Tahapan ini dilakukan untuk menghasilkan model 3 dimensi dengan membangun bidang di antara titik-titik awan 
yang memiliki nilai koordinat $\mathrm{x}, \mathrm{y}$ dan $\mathrm{z}$. Proses terakhir dalam pemrosesan citra foto udara ialah membuat orthophoto (Figure 3). Foto yang telah terkoordinat akan digabungkan menjadi satu citra drone dengan resolusi spasial yang tinggi berdasarkan dari sumber foto dan rekonstruksi model yang didapat menggunakan Agisoft's PhotoScan.

\subsection{Citra Drone}

Beberapa perlakuan seperti tingkat persentase overlapping (sidelape dan forwardlape), ketinggian penerbangan yang berbeda dan waktu akuisisi pemetaan foto udara perlu dilakukan dalam perencanaan penerbangan. Perbedaan tersebut dilakukan untuk melihat tingkat luasan dari citra drone yang dihasilkan, resolusi spasial citra drone dan waktu yang tepat untuk melalukan pemetaan menggunakan drone pada kawasan Kepulauan Seribu. Perencanaan waktu yang tepat dalam pemetaan menggunakan drone dapat terhindar dari efek pantulan sinar matahari (sunglint) yang sangat berpengaruh terhadap pemantauan objek bawah air pada citra foto udara yang dihasilkan. Citra drone yang dihasilkan dari perbedaan ketinggian menghasilkan resolusi spasial dan luasan area yang berbeda-beda. Hal ini menerangkan bahwasanya faktor besaran resolusi spasial tergantung pada ketinggian drone, semakin tinggi resolusi spasial pada citra yang dihasilkan maka penampakan objek pada gambar akan terlihat lebih detail. Penelitian Casella et al. (2016; 2017) ketinggian akuisisi drone masing-masing $80 \mathrm{~m}$ dan $30 \mathrm{~m}$, menghasilkan resolusi spasial masing-masing $2,6 \mathrm{~cm}$ dan $0,78 \mathrm{~cm}$.

\subsection{Koreksi Geometrik}

Koreksi geometrik merupakan suatu proses untuk mengoreksi kesalahan dan menandai sifat-sifat peta pada sebuah citra. Geometrik citra harus dikoreksi agar sesuai dengan peta yang digunakan dengan sistem koordinat yang dipilih, sehingga citra dapat diidentifikasi dengan baik atau titik-titik yang diamati di lapangan dapat ditemukan dengan mudah pada citra (Green et al., 2000). Teknik koreksi geometrik yang digunakan adalah transformasi titik kontrol pada citra Worldview-2 sebagai pengoreksi citra drone yang ditumpangsusunkan untuk memperoleh titik kontrol sumbu $\mathrm{X}$ (bujur) dan sumbu Y (lintang). Pasangan koordinat titik pada citra Worldview-2 dengan koordinat baru hasil estimasi, didapat selisih sepanjang sumbu $\mathrm{X}$ (bujur) dan sumbu $\mathrm{Y}$ (lintang). Titik kontrol yang didapat, selanjutnya dihitung besarnya akurasi hasil koreksi geometrik dengan persamaan Root Mean Square Error (RMSE). Citra Worldview-2 tidak dilakukan koreksi geometrik, dikarenakan sudah dikoreksi dari penyedia data yaitu Digital Globe Satellite Imagery.

\subsection{Uji Akurasi}

Uji akurasi yang dilakukan pada peta hasil klasifikasi penginderaan jauh adalah dengan matrik kesalahan (error matrix) yang mengukur akurasi (Congalton \& Green, 2009).

\section{Overall Accuracy:}

$O A=\sum_{i=1}^{k} n i i$

Producer Accuracy:

$P A=\frac{n j j}{n+j}$

User Accuracy:

$U A=\frac{n i i}{n i+}$

Keterangan: $\mathrm{k}$ ialah jumlah baris yang terdapat pada matriks, $\mathrm{n}$ ialah jumlah total pengamatan, $n j j$ ialah merupakan jumlah pengamatan pada kolom ke-j dan baris ke-j dan nii ialah jumlah pengamatan pada kolom $\mathrm{ke}-\mathrm{i}$ dan baris $\mathrm{ke}-\mathrm{i}$. 
Matriks kesalahan tunggal dan pasangan matriks kesalahan diuji tingkat kepercayaan signifikan pada standar deviasi normal sebagai berikut: Jika $\widehat{K}_{1}$ dan $\widehat{K}_{2}$ merupakan estimasi Kappa statistik dari masing-masing matriks kesalahan \#1 dan \#2, బar $\left(\widehat{K}_{1}\right)$ dan $\widehat{\text { var }}\left(\widehat{K}_{2}\right)$ ialah estimasi varian sebagai hasil dari perhitungan yang tepat, maka uji statistik untuk menentukan akurasi matriks kesalahan tunggal menggunakan persamaan,

$Z=\frac{K}{\sqrt{\widehat{\operatorname{var}}\left(\widehat{K}_{1}\right)}}$

Uji statistik untuk mengetahui jika dua matriks kesalahan independen berbeda secara signifikan dengan menggunakan persamaan:

$$
Z=\frac{\left|\widehat{K}_{1}-\widehat{K}_{2}\right|}{\sqrt{\widehat{\operatorname{var}}\left(\widehat{K}_{1}\right)+\widehat{\operatorname{var}}\left(\widehat{K}_{2}\right)}}
$$

Keterangan: $Z$ adalah standarisasi dan distribusi normal nilai kappa dengan hipotesis $H_{0}:\left(K_{1-} K_{2}\right)=0$, alternatif $H_{1}:\left(K_{l^{-}}\right.$ $\left.K_{2}\right) \neq 0, H_{0}$ ditolak jika $Z \geq Z \alpha / 2$.

\section{HASIL DAN PEMBAHASAN}

\subsection{Citra Drone}

Citra drone di Pulau Lancang dan Pulau Sebaru Besar (Figure 3) memiliki informasi ketinggian terbang, waktu akuisisi, luasan area, resolusi spasial dan tipe drone yang digunakan (Table 2).

Wahidin \& Abdullah (2018) melakukan pemetaan substrat dasar perairan dangkal menggunakan drone DJI Phantom 4 Advanced pada ketinggian $113 \mathrm{~m}$ menghasil kan resolusi spasial yang sebesar $2.61 \mathrm{~cm}$. Menurut Putra (2016) terdapat korelasi yang kuat antara tinggi terbang drone dan resolusi spasial citra yang dihasilkan. Citra drone di Pulau Lancang yaitu LC 1, LC 2, LC 3 dan LC4 dengan overlapping $70 \%$, sedangkan LC 5, LC 6 dan LC 7 dengan overlapping $80 \%$. Citra drone di Pulau Sebaru Besar yaitu SB 1, SB 2 dengan overlapping 70\%, sedangkan SB 3, SB 4 dan SB 5 dengan overlapping $80 \%$.

Perbedaan overlapping ini berdampak pada kualitas citra dan luasan yang didapat pada citra yang dihasilkan. Apabila persentase overlapping yang rendah maka pada proses orthomosaic foto udara terdapat beberapa area yang kosong (tidak memiliki objek), sehingga menyulitkan untuk melakukan visualisasi objek pada citra drone.

Table 2. Drone data tabulation.

\begin{tabular}{llccccc}
\hline Image & \multicolumn{1}{c}{ Drone type } & Height $(\mathrm{m})$ & Total photos & Acquisition & Area & Pixel $(\mathrm{cm})$ \\
\hline LC 1 & DJI Phantom 3 Pro & 50 & 246 Foto & $09.23 \mathrm{WIB}$ & $10.4 \mathrm{ha}$ & 2.3 \\
LC 2 & DJI Phantom 3 Pro & 70 & 176 Foto & $07.00 \mathrm{WIB}$ & $9.87 \mathrm{ha}$ & 2.5 \\
LC 3 & DJI Mavic Pro & 120 & 82 Foto & $17.34 \mathrm{WIB}$ & $13.4 \mathrm{ha}$ & 3.5 \\
LC 4 & DJI Phantom 3 Pro & 70 & 283 Foto & $08.37 \mathrm{WIB}$ & $14.1 \mathrm{ha}$ & 2.5 \\
LC 5 & DJI Mavic Pro & 60 & 235 Foto & $16.18 \mathrm{WIB}$ & $9.72 \mathrm{ha}$ & 2.03 \\
LC 3 & DJI Mavic Pro & 60 & 322 Foto & $13.13 \mathrm{WIB}$ & $6.99 \mathrm{ha}$ & 2.03 \\
LC 6 & DJI Mavic Pro & 50 & 354 Foto & $08.52 \mathrm{WIB}$ & $7.63 \mathrm{ha}$ & 1.6 \\
SB 1 & DJI Phantom 3 Pro & 60 & 361 Foto & $07.39 \mathrm{WIB}$ & $18.38 \mathrm{ha}$ & 3 \\
SB 2 & DJI Phantom 3 Pro & 60 & 119 Foto & $10.05 \mathrm{WIB}$ & $11.79 \mathrm{ha}$ & 3 \\
SB 3 & DJI Mavic Pro & 70 & 231 Foto & $10.18 \mathrm{WIB}$ & 9.09 ha & 2.2 \\
SB 4 & DJI Mavic Pro & 90 & 163 Foto & $08.15 \mathrm{WIB}$ & $9.75 \mathrm{ha}$ & 3 \\
SB 5 & DJI Mavic Pro & 80 & 283 Foto & $08.50 \mathrm{WIB}$ & $11.09 \mathrm{ha}$ & 2.9 \\
\hline
\end{tabular}


Semakin tinggi tingkat persentase over-lapping maka semakin tinggi compactness gambar pada citra yang dihasilkan. Pada penelitian ini pemetaan foto udara, mem butuhkan waktu berkisar 11-14 menit, dengan mempertimbangkan faktor
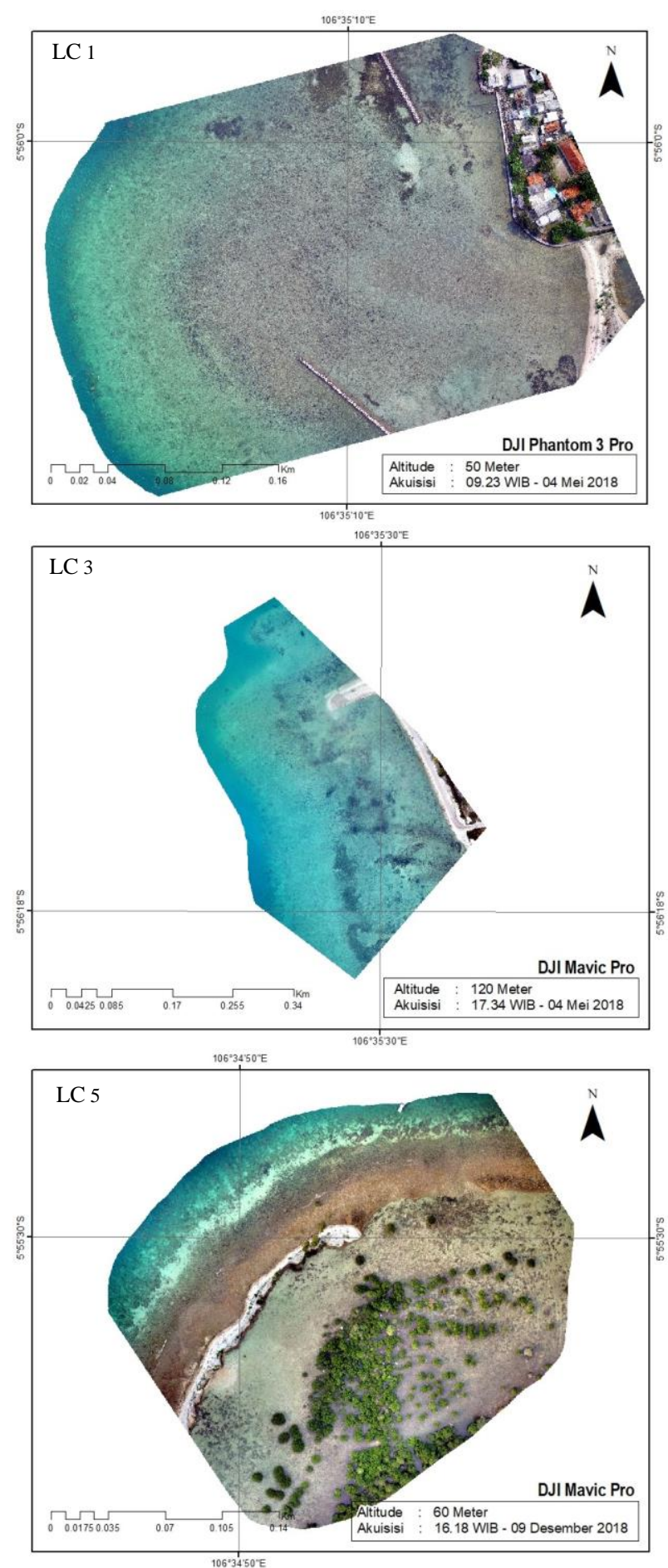

luasan area, angin dan kapasitas daya baterai. Visualisasi habitat bentik tampak jelas dan terhindar dari efek glint dan bayangan awan pada lokasi penelitian dengan akuisisi pada pukul 07.00-09.00 WIB.
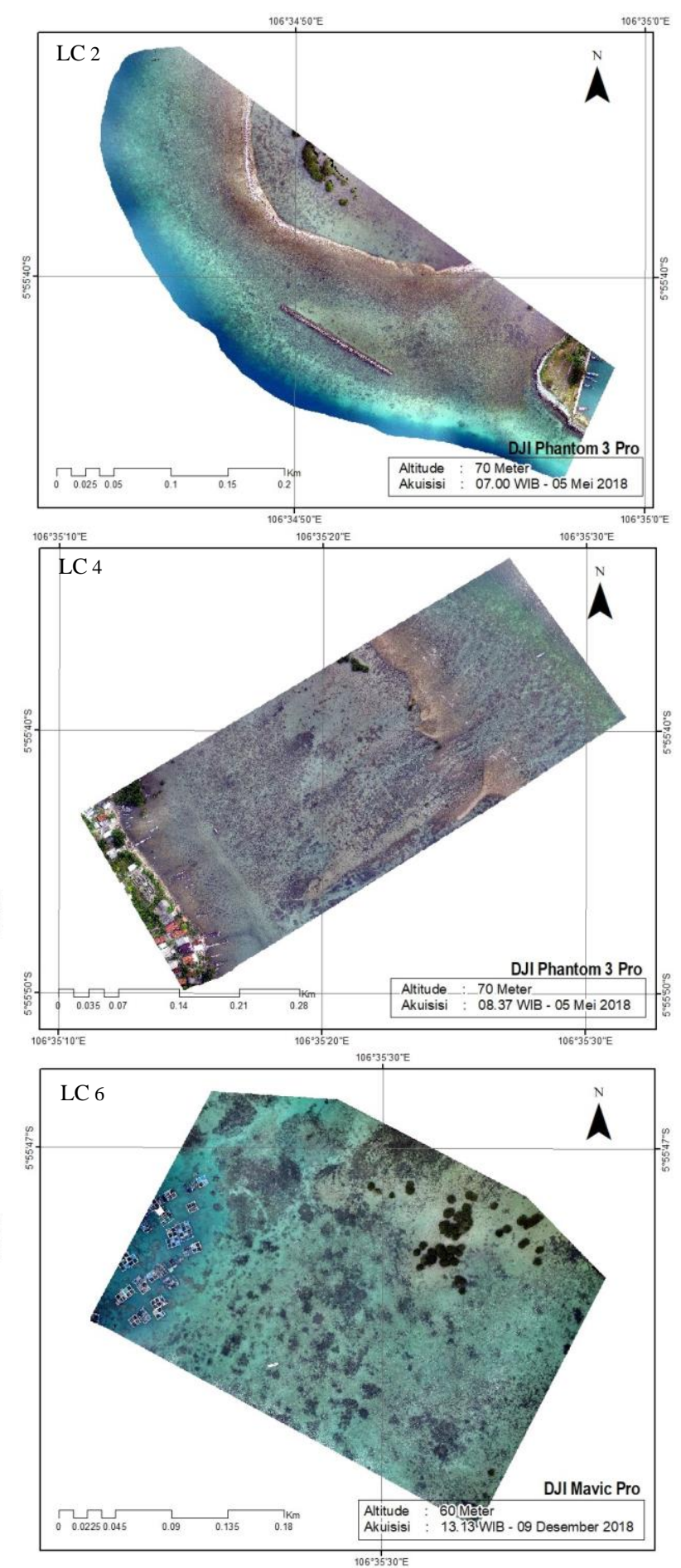

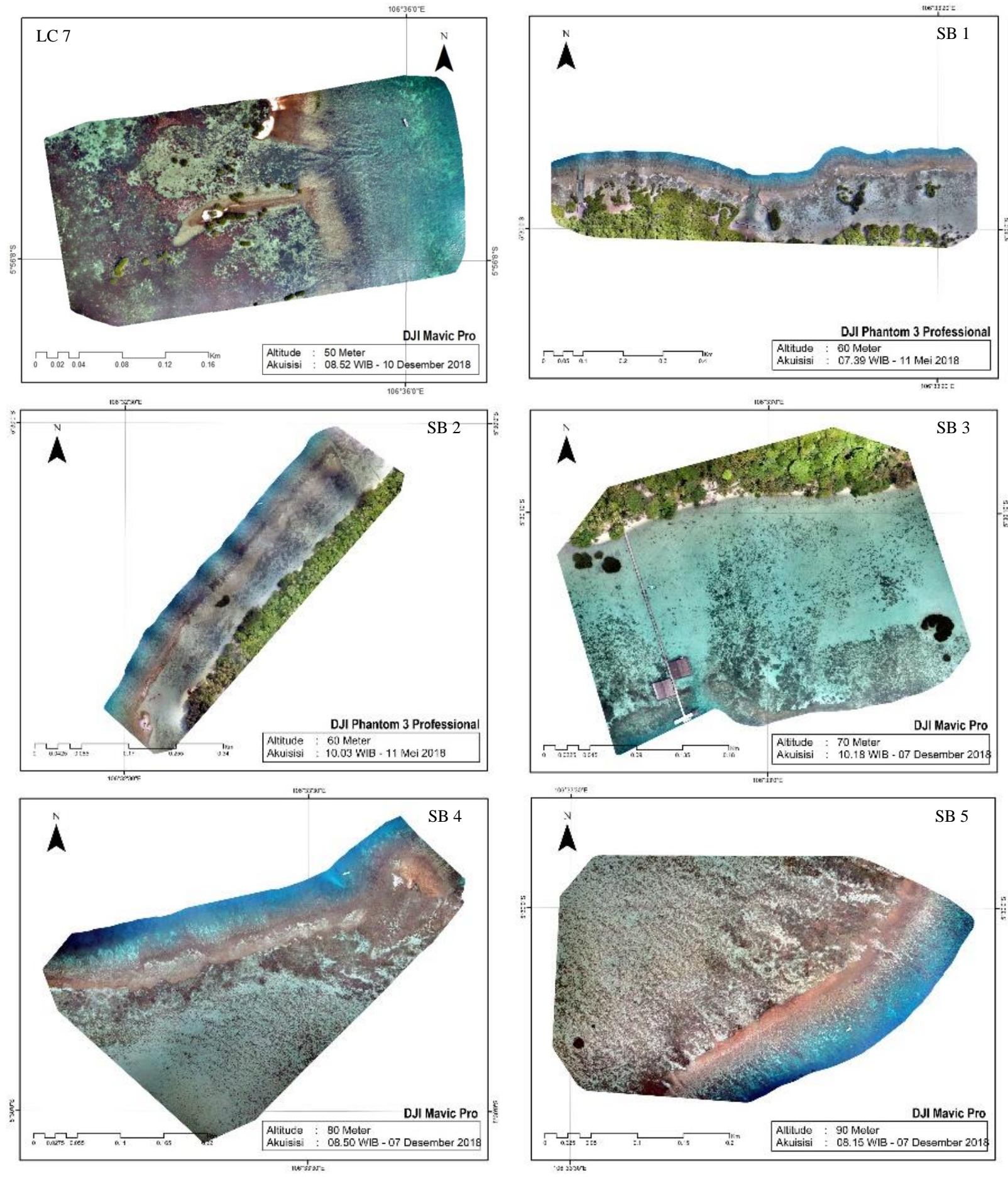

Figure 3. Aerial photography on Lancang Island (LC) and Sebaru Besar Island (SB). 

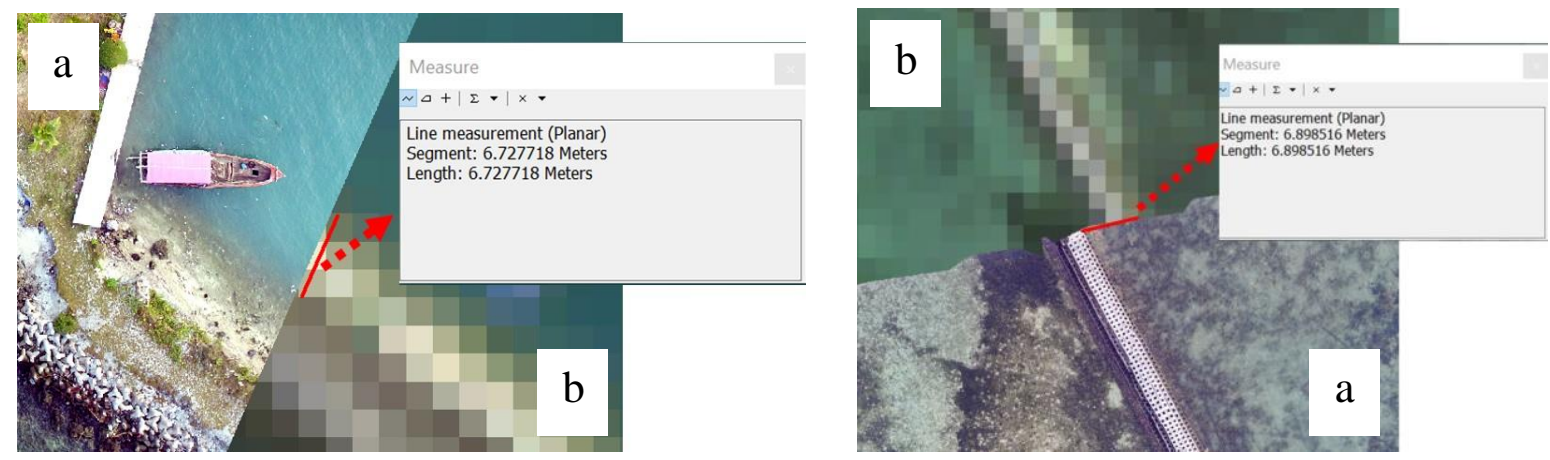

Figure 4. Overlay of aerial photograph (a) and Worldview-2 imagery (b).

\subsection{Koreksi Geometrik Citra Drone}

Koreksi Geometrik dilakukan dengan cara mentransformasikan posisi setiap piksel yang ada di citra terhadap posisi objek yang sama di permukaan bumi dengan menggunakan ground control point (GCP) (Sukojo \& Kustarto, 2002). Lokasi yang biasanya dilakukan pengambilan GCP adalah tempat/ area yang memiliki warna menyolok, per-potongan jalan, sudut jalan, perempatan jalan dan persimpangan rel dengan jalan dan bangunan yang mudah diidentifikasi atau dikenal (Darmawan, 2008).

Terdapat distorsi sekitar 6,7m-6,9m antara citra drone dan citra Worldview-2, oleh karena itu perlunya untuk dikoreksi geometrik pada citra drone dengan citra Worldview-2 sebagai pengoreksi. Pada tahap rectify dihasilkan total RMS Error 0.666291 dengan titik ikat sebanyak 8 titik tersebar di sisi citra drone yang akan dikoreksi. Nilai RMS Erorr pada citra drone yang telah dikoreksi geometrik telah memenuhi toleransi, dimana nilai RMSE tidak melebihi dan tidak sampai dengan satu. Menurut Townshend et al. (1992), akurasi dalam penyatuan sistem koordinat biasa dinyatakan dengan RMSE dengan sejumlah titik kontrol. Rentang nilai 0.5 hingga 1.0 piksel cukup untuk mencapai kesalahan $10 \%$ atau kurang dalam posisi apabila kedua citra (peta) ditumpangsusunkan masih berada dalam batasbatas toleransi.

Data citra foto udara ditumpangsusunkan dengan Citra Worldview-2 (Figure 5) untuk melihat tingkat kesusuaian posisi dilihat dengan visualisasi objek yang penampakanya jelas, seperti breakwater, pasir, dermaga dan persimpangan jalan.

\subsection{Visualisasi Objek Habitat Bentik Perairan Dangkal}

Proses visualisasi objek habitat perairan dangkal pada Citra Worldview-2 dan citra drone terlihat perbandingan secara visual (Figure 7). Perbedaan tersebut dikarenakan adanya perbedaan tingkat resolusi spasial antara Citra Worldview dan citra drone. Dimana citra Worldview-2 memiliki resolusi spasial $2 \mathrm{~m}$ sedangkan resolusi spasial citra drone biasa sampai $1,6 \mathrm{~m}$ untuk ketinggian penerbangan $50 \mathrm{~m}$.

Pengambilan data foto udara untuk proses fotogrametrik dilakukan beberapa perlakuan seperti perbedaan ketinggian, perbedaan overlapping foto. Pada penelitian (Casella et al., 2017) yang melakukan pemetaan terumbu karang menggunakan drone dan teknik fotogrametri) pada ketinggian terbang $75 \mathrm{~m}$ dan hanya mencakup perairan dangkal saja. Penggunaan drone (pesawat tanpa awak) dalam melakukan pemetaan terumbu karang sangat memungkinkan dikarenakan dengan visualisasi citra foto udara dapat melihat perbedaan pada tingkat bentuk pertumbuhan karang dengan jelas dan ukuran yang besar. Bahkan citra foto udara resolusi tinggi yang dihasilkan dengan drone, dapat diulang secara time series pada lokasi yang sama. Hal tersebut bermanfaat untuk mengkaji dampak perubahan pada tutupan terumbu 

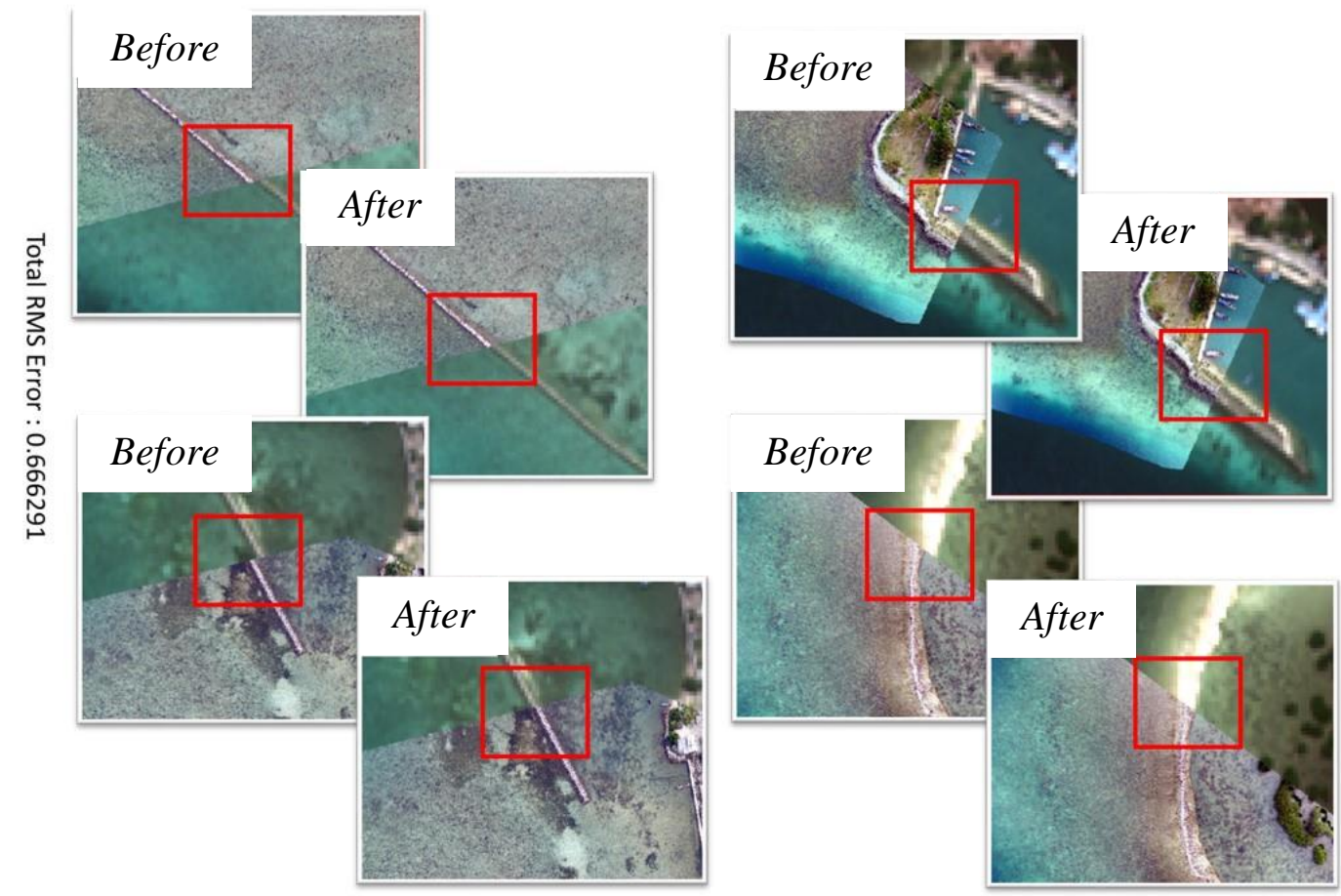

Figure 5. Aerial photograph before and after geometry correction.
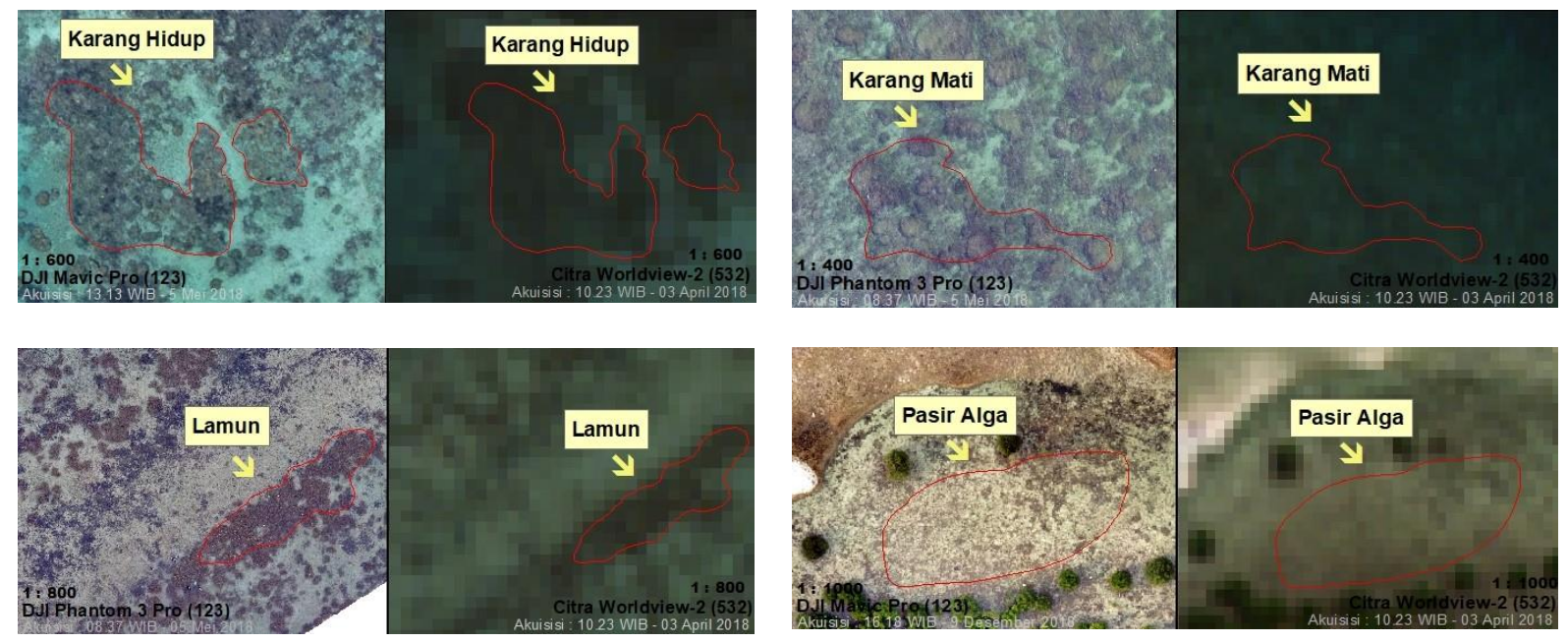

Figure 6. Visualization of benthic habitat objects on Worldview Imagery and aerial photograph.

karang yang dihubungkan dengan fenomena tertentu (Casella et al., 2017).

Resolusi spasial paling tinggi dihasilkan pada ketinggan penerbangan 50m, sedangkan resolusi spasial paling rendah dihasilkan pada ketinggian penerbangan $120 \mathrm{~m}$ dengan nilai 3.5/piksel. Wahidin \& Abdullah (2018) Pemetaan substrat dasar menggunakan drone DJI Phantom 4

Advanced pada ketinggian 113m dengan 150 foto yang di orthomosaic menghasilkan resolusi spasial sebesar $2,61 \mathrm{~cm}$.

\subsection{Klasifikasi dan Uji Akurasi Habitat Bentik Perairan Dangkal \\ Klasifikasi habitat bentik di Pulau} Lancang dan Pulau Sebaru Besar (Figure 7) menggunakan citra satelit diintegrasasi data 
GTH dan VGT. Klasifikasi yang umum digunakan selama ini adalah metode klasifikasi berbasis piksel adalah dengan algoritma maximum likelihood. Algoritma klasifikasi maximum likelihood bekerja berdasarkan nilai statistik probabilitas pada setiap training area kelas objek terhadap kelas objek yang lainnya, sehingga dapat meminimalisasi piksel yang tidak terklasifikasi melalui pengaturan nilai batas (threshold) (Richards \& Jia, 2006; Danoedoro, 2012).

Klasifikasi habitat bentik dilakukan di Pulau Lancang (Figure 7a dan b) dan Pulau Sebaru Besar (Figure 7c dan d) dengan membandingkan hasil klasifikasi dari data inputan GTH dan VGT. Hasil klasifikasi habitat perairan dangkal di Pulau Lancang dan Pulau Sebaru Besar berdasarkan warna yang terdiri dari: Alga (yellow), pasir (beryl green), lamun (green), rubble (red), karang mati (violet), karang hidup (blue), pasir campur rubble (heliotrope), pasir campur alga (topaz sand) dan rubble campur alga (green).

Hasil uji akurasi (Table 3) pada peta hasil klasifikasi dengan metode GTH dan VGT tidak berbeda secara signifikan. Citra Worldview-2 di Pulau Lancang dengan menggunakan metode GTH menghasilkan overall accuracy $65,5 \%$, sedangkan VGT $60,6 \%$. Hasil uji akurasi di Pulau Sebaru Besar dengan metode GTH juga menghasilkan overall accuracy yang lebih besar yaitu $67,5 \%$, jika dibandingkan dengan metode VGT dengan nilai sebesar 64,6\%. Akurasi yang baik dan dapat digunakan jika peta klasifikasi habitat bentik menghasilkan
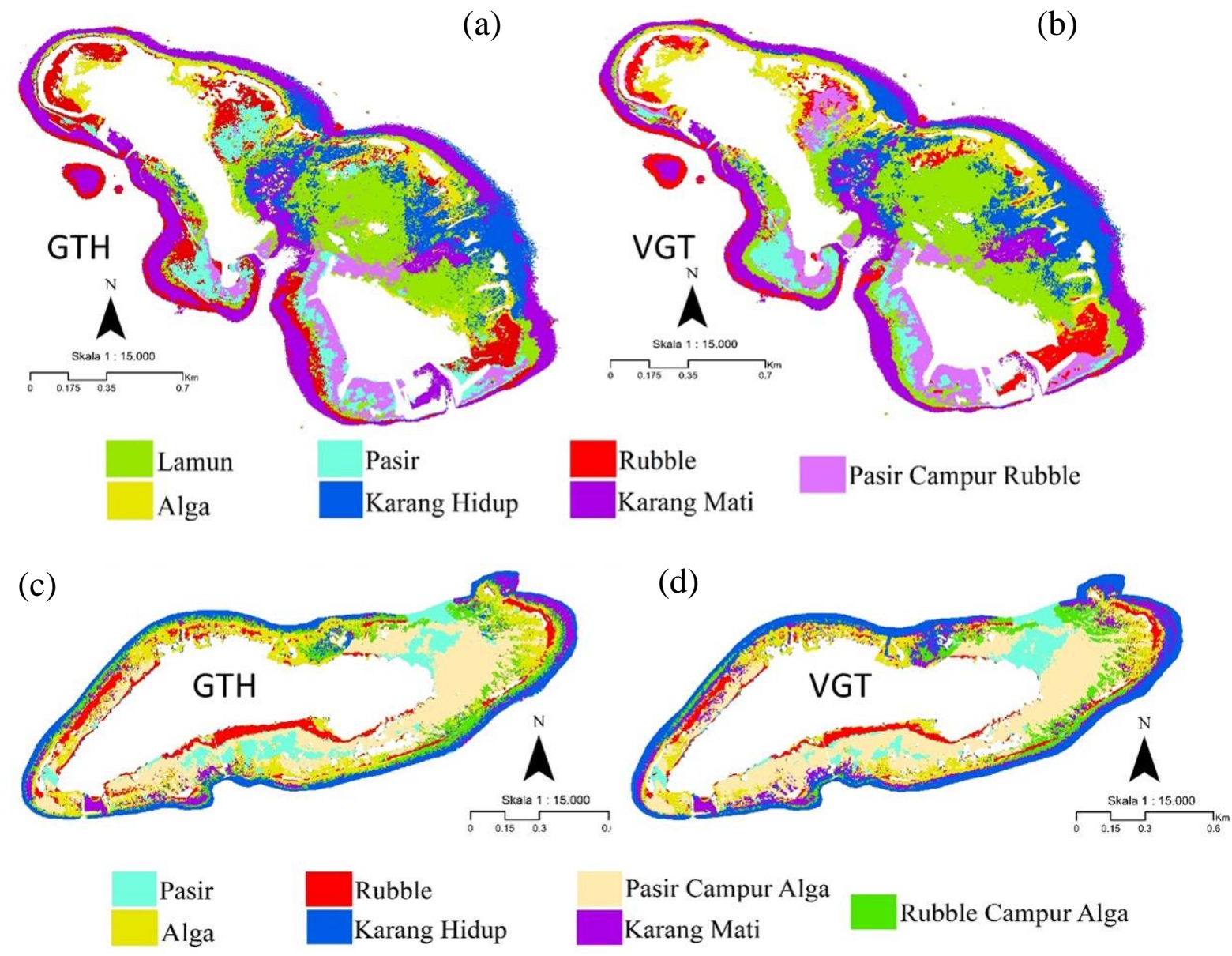

Rubble Campur Alga

Figure 7. Results of classification of shallow water benthic habitat on Lancang Island (a) GTH (b) VGT and on Sebaru Besar Island (c) GTH and (d) VGT. 
Sugara et al.

Table 3. The results of accuracy assessment and Z test on Lancang Island and Sebaru Besar Island.

\begin{tabular}{ccccccc}
\hline No. & Methods & OA & Kappa & Var. $(K)$ & $Z$ & Location \\
\hline 1 & GTH & $65.50 \%$ & 0.5948 & -0.0009 & 2.0851 & Lancang Island \\
& VGT & $60.60 \%$ & 0.5350 & 0.0017 & & \\
2 & GTH & $67.50 \%$ & 0.6162 & -0.0015 & 0.5255 & Sebaru Besar \\
& VGT & $64.60 \%$ & 0.5783 & 0.0067 & & Island \\
\hline
\end{tabular}

overall accuracy di atas 60\% (Green et al., 2000). Berdasarkan hasil penelitian sebelumnya terkait pemetaan habitat bentik perairan dangkal dengan algoritma maximum likelihood pada citra resolusi tinggi seperti Siregar (2010) dapat memetakan habitat bentik dengan akurasi $79 \%$ untuk 6 kelas habitat dengan menggunakan Citra Quickbird. Tamondong et al. (2013) dan Kabiria et al. (2018) memetakan 5 kelas habitat dengan akurasi hasil klasifikasi sebesar $75,54 \%$ dan $78,1 \%$ menggunakan Citra Worldview-2. Anggoro et al. (2018) menyatakan bahwa penggunaan Citra Worldview-2 yang diintegrasikan dengan data lapangan dapat memetakan 9 kelas habitat bentik dengan akurasi sebesar $61 \%$. Rendahnya akurasi pada penelitian ini disebabkan karena jumlah kelas habitat yang diklasifikasikan tidak sama. Menurut Mastu (2018), akurasi keseluruhan hasil pemetaan tergantung dari banyaknya kelas yang menjadi objek pemetaan. Keseluruhan hasil uji akurasi menunjukan bahwa metode GTH memiliki tingkat akurasi yang baik dibandingkan dengan VGT. Metode VGT lebih banyak terjadi kesalahan klasifikasi pada daerah yang memiliki kompleksitas tinggi. Hal ini disebabkan karena kesamaan nilai piksel pada masing-masing kelas serta kesenjangan distorsi posisi objek pada citra Worldview-2 dan citra foto udara.

Menurut Hafizt \& Danoedoro (2015) kesalahan klasifikasi terjadi dikarenakan adanya kesamaan nilai piksel seperti pada objek padang lamun dan terumbu karang. Pentingnya koreksi geo-metrik pada citra foto udara dapat menghasilkan posisi citra foto udara yang tepat dengan posisi sebenarnya pada permukaan bumi. Nilai Ztest menunjukan berbeda signifikan di Pulau Lancang sedangkan di Pulau Sebaru Besar terdistribusi secara normal. Hal ini menerangkan bahwasanya penggunaan VGT memiliki prospek kedepan untuk dilakukan di perairan dengan tingkat kekeruhan yang rendah. Menurut Congalton \& Green (2009) nilai Z-test antara nilai -1,96 sampai dengan 1,96 merupakan kategori akurasi yang berada pada distribusi normal.

\section{KESIMPULAN}

Pemetaan habitat bentik perairan dangkal dapat dipetakan dengan baik menggunakan data GTH dan VGT. Hasil overall accuracy diperoleh untuk 7 kelas habitat di Pulau Lancang dengan data GTH dan VGT masing-masing sebesar $65,5 \%$ dan 60,6\%. Sedangkan di Pulau Sebaru Besar masing-masing sebesar $67,5 \%$ dan $64,6 \%$. Perbandingan akurasi hasil klasifikasi pada data GTH dan VGT didapatkan rentang 4,9\% di Pulau Lancang dan 2,9\% di Pulau Sebaru Besar. Hasil uji signifikansi metode GTH dan VGT di Pulau Lancang berbeda nyata dengan nilai $\mathrm{Z}$ sebesar 2,0851, sedangkan di Pulau Sebaru Besar tidak berbeda nyata dengan nilai $Z$ sebesar 0,5255 , sehingga pemetaan habitat bentik dengan metode VGT dapat digunakan sebagai alternatif pengamatan di lapangan secara in-situ, namun hal ini masih memerlukan penelitian lanjutan. Berdasarkan kajian resolusi spasial citra drone dipengaruhi oleh ketinggian terbang drone dimana semakin tinggi resolusi spasial pada citra yang dihasilkan maka penampakan objek pada gambar akan 
terlihat lebih detail. Selain itu semakin tinggi persentase overlapping maka akan semakin tinggi compactness gambar pada citra yang dihasilkan.

\section{UCAPAN TERIMA KASIH}

Penelitian ini dibiayai oleh Direktorat Riset dan Pengabdian Masyarakat Ditjen Penguatan Riset dan Pengembangan Kementerian Riset, Teknologi, dan Pendidikan Tinggi, Republik Indonesia melalui program hibah Penelitian Dasar Unggulan Perguruan Tinggi (PDUPT) yang diketuai oleh Bpk. Prof. Dr. Vincentius Paulus Siregar, DEA.

\section{DAFTAR PUSTAKA}

Anggoro, A., E. Sumartono, V.P. Siregar, S.B. Agus, D. Purnama, Supriyono, D.A. Puspitosari, T. Listyorini, B. Sulistyo, \& Parwito. 2018. Comparing object-based and pixelbased classifications for benthic habitats mapping in Pari Islands. $J$. Physics: Conference Series, 1114: 1$7 . \quad$ https://doi.org/10.1088/17426596/1114/1/012049

Badan Informasi Geospasial (BIG). 2017. Peraturan Badan Informasi Geospasial Nomor 7 Tahun 2017 Tentang Kompetensi Kerja Di Bidang Informasi Geospasial. BIG. 10 p.

Casella, E., A. Collin, D. Harris, S. Ferse, S. Bejarano, V. Parravicini, J.L. Hench, \& A. Rovere. 2017. Mapping coral reefs using consumer-grade drones and structure from motion photogrammetry techniques. Coral Reefs, 36(1): 269-275.

https://doi.org/m10.1007/s00338-0161522-0

Casella, E., A. Rovere, A. Pedroncini, C.P. Stark, M. Casella, M. Ferrari, \& M. Firpo. 2016. Drones as tools for monitoring beach topography changes in the Ligurian Sea (NW
Mediterranean). Geo-Marine Letters, 36(2): 151-163.

https://doi.org/10.1007/s00338-0161522-0

Colefax, A.P., P.A. Butcher, B.P. Kelaher, Browman, \& H. He. 2017. The potential for unmanned aerial vehicles (UAVs) to conduct marine fauna surveys in place of manned aircraft. ICES J. Mar. Sci., 75(1): 1-8. https://doi.org/10.1093/icesjms/fsx10 0

Colomina, I. \& P. Molina. 2014. Unmanned aerial systems for photogrammetry and remote sensing: A review. ISPRS $J$. of Photogrammetry and Remote Sensing, 92(C): 79-97. https://doi.org/10.1016/j.isprsjprs.201 4.02.013

Congalton, R.G. \& K. Green. 2009. Assessing the accuracy of remotely sensed data-principles and practices (second edition). CRC Taylor \& Francis. France (FR). 55-127 pp.

Crutsinger, G.M., J. Short, \& R. Sollenberger. 2016. The future of UAVs in ecology: an insider perspective from the Silicon Valley drone industry. $J$. of Unmanned Vehicle Systems, 4(1): 1-8. https://doi.org/10.1139/juvs-20160008

Danoedoro, P. 2012. Pengantar Penginderaan Jauh Digital. Andi Offset. Yogyakarta (ID). $398 \mathrm{p}$.

Darmawan, S. 2008. Perkembangan teknologi geoinformasi di indonesia: Global Positioning System (GPS), Remote Sensing (RS) dan Sistem Informasi Geografis (SIG). ITB Press. Bandung.

Da-Jiang Innovations Science and Technology (DJI). 2017. Mavic Pro: User manual. DJI. 61 p.

Da-Jiang Innovations Science and Technology (DJI). 2016. Phantom 3 Professional: User manual. DJI. 57 p. 
Floreano, D. \& J.W. Robert. 2015. Science, technology and the future of small autonomous drones. Nature, 521(7553): 460-466. https://doi.org/10.1038/nature14542

Green, E.P., P.J. Mumby, A.J. Edwards, \& C.D. Clark. 2000. Remote sensing handbook for tropical coastal management. UNESCO Pub. Paris (FR). 316 p.

Hafizt, M. \& P. Danoedoro. 2015. Kajian pengaruh koreksi kolom air pada citra multispektral worldview-2 untuk pemetaan habitat bentik di Pulau Kemujan Kepulauan Karimunjawa Kabupaten Jepara. Kongres Vi Mapin 2015. Mapin Jabodetabek. Bogor. 566-574 pp.

Hedley, J.D., C.M. Roelfsema, I. Chollett, A.R. Harborne, S.F. Heron, S. Weeks, W.J. Skirving, A.E. Strong, C.M. Eakin, T.R.L. Christensen, V. Ticzon, S. Bejerano, \& P.J. Mumby. 2016. Remote sensing of coral reefs for monitoring and management: a review. Remote Sensing, 8: 118-157. https://doi.org/10.3390/rs8020118

Kabiria, K., H. Rezaib, \& M. Moradia. 2018. Mapping of the corals around Hendorabi Island (Persian Gulf), using Worldview-2 standard imagery coupled with field observations. Marine Pollution Bulletin, 129: 266274.

https://doi.org/10.1016/j.marpolbul.2 018.02 .045

Kiszka, J.J., J. Mourier, K. Gastrich, \& M.R. Heithaus. 2016. Using unmanned aerial vehicles (UAVs) to investigate shark and ray densities in a shallow coral lagoon. Marine Ecology Progress Series, 560: 237-242. https://doi.org/10.3354/meps 11945

Kohler, K.E. \& S.M. Gill. 2006. Coral point count with excel extensions (cpce): A visual basic program for the determination of coral and substrate coverage using random point count methodology. Computers dan Geosciences, 32: 1259-1269.

https://doi.org/10.1016/j.cageo.2005.11.009

Mastu, L.O.K., B. Nababan, \& J.P. Panjaitan. 2018. Pemetaan habitat bentik berbasis objek menggunakan citra sentinel-2 di Perairan Pulau WangiWangi Kabupaten Wakatobi. J. Ilmu dan Teknologi Kelautan Tropis, 10(2): 381-396.

https://doi.org/10.29244/jitkt.v10i2.21039

Mellin, C., S. Andrefouet, M. Kulbicki, M. Dalleau, \& L. Vigliola. 2009. Remote sensing and fish habitat relationship in coral reef ecosystem: review and pathways for systematic multiscale hierarchical research. Marine Pollution Bulletin, 58: 11-19. https://doi.org/10.1016/j.marpolbul.2 008.10.010

Putra, A.S., W. Ambarwulan, E. Maulana, T.R. Wulan, N. Maulia, M.D. Putra, D.S. Wahyuningsih, F. Ibrahim, \& T. Raharjo. 2016. Kajian korelasi antara tinggi terbang dan resolusi foto udara hasil akuisisi dengan UAV di Kawasan Pesisir. Prosiding Seminar Nasional Kelautan 2016. Universitas Trunojoyo Madura, 27 Juli 2016. 216-225 pp.

Ratcliffe, N., D. Guihen, J. Robst, S. Crofts, A. Stanworth, \& P. Enderlein, 2015. A protocol for the aerial survey of penguin colonies using UAVs. $J$. Unmanned Vehicle Systems, 3(3): 95101. https://doi.org/10.1139/juvs2015-0006

Richards, J.A. 2013. Remote sensing digital image analysis; Springer: Berlin, Germany. 295-332 pp.

Richards, J. \& X. Jia. 2006. Remote sensing digital image analysis. Springer, Berlin. 194-199 pp.

https://www.springer.com/gp/book/97 83540297116

Roelfsema, C. \& S. Phinn. 2008. Evaluating eight field and remote sensing approaches for mapping the benthos 
of three different coral reef environments in fiji. Remote Sensing of Inland, Coastal, and Oceanic Waters, 7150(F): 1-14. https://doi.org/10.1117/12.804806

Schaub, J., B.P. Hunt, E.A. Pakhomov, K. Holmes, Y. Lu, \& L. Quayle. 2018. Using unmanned aerial vehicles (UAV's) to measure jellyfish aggregations. Marine Ecology Progress Series, 591: 29-36. https://doi.org/10.3354/meps12414

Siregar, V. 2010. Pemetaan substrat dasar perairan dangkal karang congkak dan lebar Kepulauan Seribu menggunakan citra satelit quick bird. J. Ilmu dan Teknologi Kelautan Tropis, 2(1): 1930. https://doi.org/10.29244/jitkt.v2i1.78 60

Sukojo, B.M. \& H. Kustarto. 2002. Perbaikan geometrik trase jaringan jalan dengan menggunakan teknologi penginderaan jauh dan sistem informasi geografis. J. Makara, Sains, 6(3): 136-141.

Sulong, I., H.M. Lokman, K.M. Tarmizi, \& A. Ismail. 2002. Mangrove mapping using Landsat imagery and aerial photographs: Kemaman District, Terengganu, Malaysia. Environment, Development and Sustainability, 4(2): 135-152. https://doi.org/10.1023/A:102084462 0215
Tamondong, A.M., A.C. Blanco, M.D. Fortes, \& K. Nadaoka. 2013. Mapping seagrass and other benthic habitats in Balinao, Pangasinan using Worldview-2 Satellite Image. International Geoscience and Remote Sensing Symposium. IEEE. 1579$1582 \mathrm{pp}$. https://doi.org/10.1109/IGARSS.2013 .6723091

Townshend, J.R.G., C.O. Justice, C. Gurney, \& J. McManus. 1992. The impact of misregistration on change detection. IEEE Transactions on Geoscience and Remote Sensing, 30(5): 1054-1060. https://doi.org/10.1109/36.175340

Wahidin, N. \& R.M. Abdullah. 2018. Pemetaan substrat dasar perairan dangkal menggunakan drone komersial dan teknik fotogrametri. Prosiding Seminar Nasional Inovasi Iptek Perikanan dan Kelautan I. Juni 2018. 621-633 pp.

Waugh. E. \& M. Mowlem. 2010. Technical note: a low cost unmanned aerial vehicle for ship based science missions. Copernicus Publications on behalf of the European Geosciences Union. Ocean Science, 6(3): 615-619. https://doi.org/10.5194/os-6-615-2010

$\begin{array}{ll}\text { Received } & : \text { 28 June } 2019 \\ \text { Reviewed } & : \text { O7 October } 2019 \\ \text { Accepted } & : \text { O1 March } 2020\end{array}$

